\title{
Tekirdağ Merkez İlçesindeki Bazı Akarsu Yataklarındaki Toprakların Özellikleri
}

\author{
Bahadır ATMACA * $\quad$ Duygu BOYRAZ ERDEM² \\ 'Giresun Üniversitesi Șebinkarahisar Uygulamalı Bilimler Yüksekokulu Gıda Teknolojisi Bölümü, Giresun \\ ${ }^{2}$ Namık Kemal Üniversitesi Ziraat Fakültesi Toprak Bilimi ve Bitki Besleme Bölümü, Tekirdağ
}

\begin{abstract}
*Sorumlu yazar e-posta (Corresponding author e-mail): bahadiratmaca23@gmail.com
Geliș tarihi (Received) : 19.10.2015

Kabul tarihi (Accepted) : 25.04.2016
\end{abstract}

Öz

Bu çalıșma, akarsu yataklarındaki topraklar için bir veri tabanı olușturmak amacıyla yapılmıștır. Bu amaçla Tekirdağ Merkez ilçesindeki bazı akarsu yataklarındaki arazilerin fiziksel ve kimyasal özellikleri belirlenmiștir. Araștırma alanında incelenen drenaj ağ sistemleri, birbirlerine paralel ve denize dik ve yarı paralel (subparalel) drenaj ağ sistemleridir. Akarsu yataklarından yüzey toprağı olarak alınan örneklerde; tekstür, pH, tuz, kireç, organik madde, hidrolik iletkenlik ve bazı makro ve mikro element analizleri yapılmıștır. Yapılan değerlendirmeler sonucunda, pH değerleri genellikle nötr olarak bulunan yüzey topraklarında tuzluluk sorununa rastlanmamıștır. Yüzey topraklarının kireç ve organik madde kapsamları genellikle az olarak saptanırken, demir, bakır ve manganın yeterli olduğu bulunmuștur. Fakat çinko noksanlığı tespit edilmiștir. Toprak örneklerinin yarayıșı fosfor ve değișebilir potasyum içerikleri genellikle yeterlidir. Toprakların büyük bir kısmı kil tekstür sınıfında olduğu için yavaș hidrolik iletkenliğe sahiptirler. Toprakların mevcut fiziksel ve kimyasal özelliklerinin korunması ve eksik yönlerinin iyileștirilmesi için bașta ahır gübresi olmak üzere diğer gübreler kullanılmalıdır. Toprak ișleme, sulama gibi diğer tarımsal uygulamalar için gerekli önlemler alınmalıdır.

Anahtar Kelimeler: Akarsu yatakları, alüviyal topraklar, toprak verimliliği

\section{Properties of Soils in Some Streambeds in Tekirdag Central District}

\footnotetext{
Abstract

This study was made in order to create a database for soils in streambeds. For this purpose, physical and chemical properties of lands in some streambeds in Tekirdag Central district have been specified. The drainage network systems, examined at the research area, are drainage network systems that are parallel to one another and that are vertical and semi-parallel (sub-parallel) to the sea. In samples taken from streambeds as the surface soil; texture, $\mathrm{pH}$, salt, lime, organic matter, hydraulic conductivity analyses and some macro and micro element analyses were made. As a result of the assessments made, there was no saltiness problem encountered in the surface soils and their $\mathrm{pH}$ values have been found to be generally neutral. While the lime and organic matter scopes of the surface soils have been determined to be generally small, iron, copper and manganese have been found sufficient. But zinc deficiency has been identified. Available phosphorus and exchangeable potassium contents of soil samples are generally sufficient. Because the majority of soils are in a clay texture class have a slow hydraulic conductivity. Other fertilizers should be used, especially barnyard manure for improving of disadvantages and
} 
protection of current physical and chemical properties of soils. Necessary measures must be taken for the other agricultural applications as tillage, irrigation.

Key Words: Streambeds, alluvial soils, soil productivity

\section{Gíiș}

Akarsuların zamanla tașıdığı depozitler üzerinde olușmuș alüviyal topraklar kısa mesafeler içerisinde çok farklı özellikler göstermekte ve birbirinden farklı topraklar olușabilmektedir. Alüviyal topraklar fiziksel, kimyasal ve morfolojik özellikleri, alüvyon kaynaklandığı ana materyalin özelliği, tașınma ve birikme sırasında meydana gelen değișmeler sonucu çok kompleks bir olușum göstermektedirler (Dengiz ve Gülser, 2014). Alüviyal topraklar birtakım sorunlar (tuzluluk, alkalilik, drenaj vb.) içermelerine karșılık tarımsal kullanımlar için önemli potansiyele sahip topraklardır. Bu toprakların üretken olmaları, genellikle düz-düze yakın topoğrafyalarda yer almalarının yanı sıra, bitkilere yeteri kadar kök derinliği sağladıkları gibi kolay ayrıșabilen, birçok besin elementlerini içermelerindendir. Dolayısıyla bu toprakların birbirinden farklı çok değișken özelliklere sahip olması, yönetim isteklerinin de birbirinden farklı olmasına neden olmaktadır (Dengiz ve Sarıoğlu, 2011 ).

Ana materyali alüviyaller olan, Yeșilırmak nehir terasları üzerinde olușmuș topraklar incelendiğinde, toprakların $\mathrm{pH}$ değerlerinin 7,38-8,41 arasında değiștiği, kireç miktarlarının \% 0,8-25,4 değerleri arasında olduğu ve toprakların büyük çoğunluğunun organik madde içeriklerinin düșük düzeyde olduğu saptanmıștır (Durak ve Aydın, 2014). Tekirdağ Merkez Bağlar sırtları mevkiinde yer alan araștırma topraklarının $\mathrm{pH}$ 'larının genelde nötral olduğu, tuzluluk sorunlarının olmadığı, genellikle az kireçli oldukları, orta ve az miktarda organik madde içerdikleri ve tekstürlerinin de genelde killi ve killi tınlı bir yapıda olduğu belirlenmiștir (Sarı, 2010). Tekirdağ ilindeki araștırma topraklarının $\mathrm{pH}$ değerleri 5, 10 ile 8,00 arasında geniș bir dağııım gösterirken, \% tuz değerlerine göre bütün topraklar 'tuzsuz' sınıfında olup, toprakların \% 90'ı organik maddece yetersiz ve yarayıșlı fosfor içerikleri 5,03 ppm ile 75,72 ppm arasındadır (Bellitürk ve Sağlam, 2005).

Tekirdağ Merkez ilçesinin kıyı șeridinde yer alan drenaj ağındaki dere yataklarından alınan toprak örnekleri genellikle kil tekstür sınıfında ve yavaș hidrolik iletkenliğe sahiptirler (Atmaca ve Boyraz, 2015). Tekirdağ yöresindeki araștırma topraklarının \% 85'inde organik maddenin yetersiz olduğu gözlenmiștir (Bellitürk vd., 2009). Bursa Ili'ndeki alüviyal araștırma topraklarının \% 43,39'u organik madde, \% 46,66'sı azot, \% 10'u fosfor ve \% 20'si kükürt, \% 43,34'ü çinko ve \% 90'ı mangan bakımından yetersiz olarak belirlenmiș ve bu noksanlıkların yanında toprakların \% 23,33'ünde değișebilir potasyum, \% 43,33'ünde kalsiyum, \% 73,33'ünde magnezyum, \% 50'sinde bitkiye yarayıșlı fosfor, \% 90'ında demir ve \% 100'ünde bakırın yeterli olduğu ortaya konulmuștur (Turan vd., 2010).

Trakya Bölgesi'nin sahil șeridi boyunca denize dik ve birbirlerine paralel ve yarı paralel bağlanan drenaj ağları, akarsuların kaynağından itibaren çeșitli materyaller tașımıștır. Bu tașınan materyaller akarsuların geçirdiği evrelerle birlikte dere yataklarını olușturmuștur. Bu çalıșmada, Tekirdağ Merkez ilçesinde yer alan bazı akarsu yataklarından alınan yüzey toprağı örneklerinin bazı fiziksel ve kimyasal özelliklerinin belirlenmesi ve değerlendirilmesi ile birlikte akarsu yataklarındaki topraklar için bir veri tabanı olușturulması amaçlanmıștır.

\section{MATERYAL VE YÖNTEM}

Arazide çalıșma yapılacak noktaların belirlenmesi için, Köy Hizmetleri Tekirdağ il Müdürlüğü'nden alınan 1/25.000 ölçekli standart topoğrafik haritalardan, Anonim (1 972)'e göre eski toprak sınıflaması ve 1/500.000 ölçekli jeolojik haritalardan yararlanıımıștır. Araștırma alanındaki toprak örnekleme noktalarının koordinatlarını belirlemek ve yerlerini șekil üzerinde göstermek amacılla, internet üzerinden elde edilen GoogleEarth 7.1.2.2041 sürümü kullanılmıștır (Anonim, 2015). Bozulmuș toprak örnekleri, bölgede drenaj ağ sistemlerinin etkisiyle ayrıcalık gösterdikleri saptanan yerlerden (Șekil 1 ve Çizelge 1); yüzey toprağı olarak, kovalı burgu, yarı kovalı burgu, tirbușon burgu, kazma ve kürek yardımıyla 


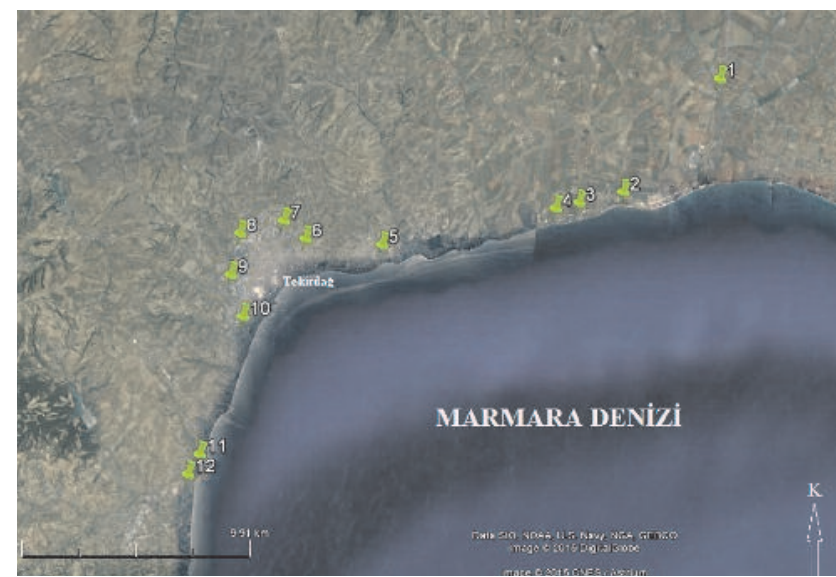

Sekil 1. Google-Earth 2015 görüntüsü üzerinde toprak örnekleme noktaları

Figure 1. Soil sampling points on Google-Earth 2015 image

alınmıștır. 1 numaralı Örnek 0-15 cm, 5 numaralı örnek 0-10 cm ve diğer örnekler de 0-30 cm derinliklerinden alınmıștır. Araziden alınan toprak örnekleri laboratuvar koșullarında kurutulduktan sonra, tahta tokmakla dövülerek ve 2 mm'lik elekten geçirilerek analizlere hazır hale getirilmiștir (Sağlam, 2001). Örneklerin makro ve mikro element analizleri paralelli olarak yapılmıș ve ortalamalar hesaplanarak sonuçlar yazılmıștır.

Tekstür, Bouyoucos hidrometre yöntemi kullanılarak belirlenmiștir (Bouyoucos, 1951). Toprak reaksiyonu (pH) değerleri, 1:2,5 (toprak:su) oranında sulandırılmıș olan toprak süspansiyonlarında cam elektrodlu pH-metre ile ölçülerek Jackson (1958)'a göre belirlenmiștir. Tuz (\%), Richards (1954)'a göre, 1:2,5 (toprak:su) oranında sulandırılmıș olan toprak süspansiyonlarında Wheatstone Bridge (elektriki iletkenlik cihazı) ile ölçülerek belirlenmiștir. Kireç (\%), kalsimetre metodu ile; organik madde, SmithWeldon metodu ile belirlenmiștir (Sağlam, 2001). Smith-Weldon metodu ile elde edilen \% Organik-C ile 1,724 değeri çarpılmıș ve organik madde (\%) hesaplanmıștır. Hidrolik iletkenlik değerleri, bozulmuș toprak örneklerinde Tüzüner (1990)'e göre belirlenmiștir.

Yarayıșlı fosfor $\left(\mathrm{P}_{2} \mathrm{O}_{5}\right)$, Olsen metodu ile ICP cihazında belirlenmiștir (Olsen vd., 1954). Değișebilir potasyum $\left(\mathrm{K}_{2} \mathrm{O}\right)$, toprak örneklerinin amonyum asetat ile ekstrakte edilerek (Sağlam, 2001), ICP (Inductively coupled plasma) cihazında okunmalarıyla belirlenmiștir. Fe, Cu, $\mathrm{Zn}$ ve $\mathrm{Mn}$ değerleri, araștırma topraklarının DTPA (Dietilen triamin penta asetik asit) ile ekstrakte edilerek, ICP cihazında okunmalarıyla belirlenmiștir (Sağlam, 2001). Toprak örneklerinin bazı makro ve mikro element değerlerinin standart sapmaları Soysal (2000)'a göre hesaplanmıștır.

\section{BULGULAR VE TARTIȘMA}

Araștırmada kullanılan 12 adet yüzey toprağı örneğine ait bazı fiziksel ve kimyasal analiz sonuçları Çizelge 2'de verilmiștir. Buna göre, toprakların pH'ları 6, 64-7,64 değerleri arasında değișmektedir. Hafif alkali toprak reaksiyonuna sahip 5 numaralı örneğin haricindeki diğer tüm örneklerin pH'ları nötr olarak bulunmuștur. Toprak reaksiyonu sınıflandırması, nötr için 6,5-7,5 ve hafif alkali için 7,5-8,5 sınır değerleri dikkate alınarak, Alpaslan vd., (2005) tarafından belirtildiği șekilde yapılmıștır. Tüm toprak örneklerinin tuz değerleri \% 0,15'in altında

Çizelge 1 . Toprak örnekleme noktalarının koordinatları ve dere yatakları

Table 1. Coordinates of soil sampling points and streambeds

\begin{tabular}{|c|c|c|c|}
\hline \multirow{2}{*}{$\begin{array}{c}\text { Örnek } \\
\text { No. }\end{array}$} & \multicolumn{2}{|c|}{ Koordinatlar } & \multirow[t]{2}{*}{ Dere Yatakları } \\
\hline & Enlem & Boylam & \\
\hline 1 & $41^{\circ} 2^{\prime} 58,99 " \mathrm{~K}^{\prime}$ & $27^{\circ} 44^{\prime} 3,71 " D^{2}$ & Hacımuratlı Aktif Deresi \\
\hline 2 & $41^{\circ} 0.18,26 " \mathrm{~K}$ & $27^{\circ} 41^{\prime} 0,41^{\prime \prime D}$ & Ağılovası Aktif Deresi \\
\hline 3 & $41^{\circ} 0.3,17 " \mathrm{~K}$ & 2739'37,58"D & Derince Aktif Deresi \\
\hline 4 & $40^{\circ} 59^{\prime} 55,09 " \mathrm{~K}$ & $27^{\circ} 38^{\prime} 54,26 " \mathrm{D}$ & Menekșe Aktif Deresi \\
\hline 5 & $40^{\circ} 59 ' 3,24 " \mathrm{~K}$ & $27^{\circ} 33^{\prime} 27,13^{\prime \prime D}$ & Aydınpınar Kuru Deresi \\
\hline 6 & $40^{\circ} 59^{\prime} 11,41 " \mathrm{~K}$ & $27^{\circ} 31^{\prime} 4,91 " \mathrm{D}$ & Domlu Kuru Deresi \\
\hline 7 & $40^{\circ} 59 ' 37,06 " \mathrm{~K}$ & $27^{\circ} 30^{\prime} 24,75^{\prime \prime} \mathrm{D}$ & Domlu Kuru Deresi \\
\hline 8 & $40^{\circ} 59^{\prime} 19,08 " \mathrm{~K}$ & $27^{\circ} 29^{\prime} 2,41 " \mathrm{D}$ & Nailçavuș Deresi \\
\hline 9 & $40^{\circ} 58^{\prime} 20,54^{\prime \prime} \mathrm{K}$ & $27^{\circ} 28^{\prime} 45,15^{\prime \prime D}$ & Köseoğlu Aktif Deresi \\
\hline 10 & $40^{\circ} 57^{\prime} 21,45^{\prime \prime} \mathrm{K}$ & $27^{\circ} 29^{\prime} 7,19 " \mathrm{D}$ & Nailçavuș Deresi \\
\hline 11 & $40^{\circ} 54^{\prime} 4,88^{\prime \prime} \mathrm{K}$ & $27^{\circ} 27^{\prime} 47,58 " \mathrm{D}$ & Barbaros Aktif Deresi \\
\hline 12 & $40^{\circ} 53 ' 36,67^{\prime \prime} \mathrm{K}$ & $27^{\circ} 27^{\prime} 25,78 " \mathrm{D}$ & Koca Aktif Deresi \\
\hline
\end{tabular}

'Kuzey, ${ }^{2}$ Doğu 
olduğu için, Richards (1954) tarafından bildirildiği șekilde tuzsuz olarak sınıflandırılmıșlardır. Toprakların kireç miktarları \% 1,11 ile \% 12,32 arasında değișmektedir. 3, 6, 8 ve 9 no'lu örnekler kireçli (\% 5-10), 5 no'lu örnek çok kireçli (\% 10-25), diğer örnekler de az kireçli (1\% 1-5) olarak sınıflandırılmıștır. Kireç sınıflandırması Cangir (1991)'e göre yapılımıștır. Araștırma topraklarının organik madde miktarları \% 0,92 ile \% 1,96 arasında değișmektedir. 5 ve 6 no'lu örneklerin çok az miktarda $(<\% 1)$ ve geriye kalan 10 adet örneğin de az miktarda (\% 1-2) organik madde içerdikleri belirlenmiștir. Organik madde değerleri Alpaslan vd., (2005) tarafından bildirildiği șekilde sınıflandırılmıștır.

Sinan (1996)' a göre, Tekirdağ ile Marmara Ereğlisi arasında yer alan ve Marmara Denizi'nin etkisi altında kalan kıyı bandı topraklarında, $\mathrm{pH}$ 6,77-7,80 arasındadır. Kireç, önemli ölçüde üst topraktan yıkanmıș ve birikme alt toprakta meydana gelmiștir. Tekstür sınıfları açısından topraklar ağır bünyeli olup, organik madde içerikleri azdır ve örneklerde tek bir örnek hariç önemli bir tuz problemi yoktur. İspanya Cadiz'de, Rio Fraja vadisindeki holosen alüviyal çökellerde yer alan yüzey toprağı $(0-30 \mathrm{~cm})$ analiz edilmiș ve kum, silt ve kil içerikleri sırasıyla \% 68, \% 27 ve \% 5 olarak bulunmuștur. Toprak reaksiyonu $(\mathrm{pH})$ 7,9 ve kireç \% 9,2 olarak saptanmıștır (Faust vd., 2000).

Araștırmada kullanılan toprak örneklerinden 8 adet örneğin kil tekstür sınıfında, 1 no'lu örneğin siltli kil, 3 no'lu örneğin tın, 9 no'lu örneğin killi tın ve 11 no'lu örneğin de kumlu killi tın tekstür sınıfında olduğu saptanmıștır. Toprakların tekstür sınıflarının isimlendirilmesi Soil Survey Division Staff (1993)'a göre yapılmıștır. Toprak örneklerinin hidrolik iletkenlik değerleri $0,13 \mathrm{~cm} \mathrm{~h}^{-1}$ ile $2,35 \mathrm{~cm}$ $\mathrm{h}^{-1}$ arasında değișiklik göstermektedir. $11 \mathrm{No} / \mathrm{lu}$ örnek, diğer örneklerle karșılaștırıldığında, en yüksek hidrolik iletkenlik değerine sahiptir $(2,35 \mathrm{~cm}$ $\mathrm{h}^{-1}$ ) ve Tüzüner (1990) tarafindan bildirildiğine göre orta $\left(2-6,25 \mathrm{~cm} \mathrm{~h}^{-1}\right)$ hidrolik iletkenlik sınıfındadır. Diğer tüm toprak örneklerinin hidrolik iletkenlikleri orta yavaș $\left(0,5-2 \mathrm{~cm} \mathrm{~h}^{-1}\right)$ ve yavaș $\left(0,125-0,5 \mathrm{~cm} \mathrm{~h}^{-1}\right)$ olarak sınıflandırıımıștır. Antakya'da eski göl tabanı üzerinde olușmuș olan çalıșma alanı topraklarının doymuș hidrolik iletkenlik değerleri çok düșük olarak saptanmıștır (Keskin, 1998).

Araștırma topraklarının bazı makro ve mikro element içeriklerini tespit ederken laboratuvarda paralelli çalıșılmıș ve ortalamalar hesaplanarak elde edilen sonuçlar ve bu sonuçların standart sapma değerleri Çizelge 3'te verilmiștir. Toprakların yarayıșlı fosfor $\left(\mathrm{P}_{2} \mathrm{O}_{5}\right)$ değerleri $1,48 \mathrm{~kg} \mathrm{da}^{-1}$ ile 26,35 kg da-1 arasında değișmektedir. 1, 8, 9, 11 ve 12 no'lu örneklerin yüksek miktarda (> 12 kg da1): 2, 3, 4, 7 ve 10 no'lu örneklerin orta seviyede (4-12 kg da ${ }^{-1}$ ); 5 ve 6 no'lu örneklerin de çok düșük miktarda $\left(<4 \mathrm{~kg} \mathrm{da}^{-1}\right)$ yarayıșlı fosfor $\left(\mathrm{P}_{2} \mathrm{O}_{5}\right)$ içerdikleri belirlenmiștir. Yarayıșlı fosfor için sınır değerleri Olsen ve Dean (1965) tarafından bildirilmiștir. Orta seviyede ve çok düșük miktarda yarayıșlı fosfor içeren topraklarda fosforlu gübre uygulaması yapılarak fosfor yeterli seviyeye getirilebilir. Brunei Darussalam'da, pirinç yetiștirilen tarımsal kalkınma alanlarındaki toprak örneklerinde

Çizelge 2. Toprakların bazı fiziksel ve kimyasal analiz sonuçları

Table 2. Some physical and chemical analysis results of soils

\begin{tabular}{cccccccccc}
\hline $\begin{array}{c}\text { Örnek No. } \\
\text { ve } \\
\text { Derinlik (cm) }\end{array}$ & $\begin{array}{c}\mathrm{pH} \\
(1: 2,5 \\
\text { Su) }\end{array}$ & $\begin{array}{c}\text { Tuz } \\
(\%)\end{array}$ & $\begin{array}{c}\text { Kireç } \\
(\%)\end{array}$ & $\begin{array}{c}\text { Org. } \\
\text { Mad. } \\
(\%)\end{array}$ & $\begin{array}{c}\text { Kum } \\
(\%)\end{array}$ & $\begin{array}{c}\text { Tekstür } \\
\text { Silt } \\
(\%)\end{array}$ & $\begin{array}{c}\text { Kil } \\
(\%)\end{array}$ & $\begin{array}{c}\text { Tekstür } \\
\text { Sinıfi }\end{array}$ & $\begin{array}{c}\text { Hidrolik } \\
\text { Iletkenlik } \\
\left(\mathrm{cm} \mathrm{h} ~^{-1}\right)\end{array}$ \\
\hline $1(0-15)$ & 7,12 & 0,05 & 4,42 & 1,96 & 13,09 & 40,04 & 46,87 & SiC & 0,73 \\
$2(0-30)$ & 7,30 & 0,06 & 3,16 & 1,80 & 22,01 & 29,32 & 48,67 & $\mathrm{C}$ & 0,82 \\
$3(0-30)$ & 7,18 & 0,03 & 7,11 & 1,60 & 37,92 & 35,32 & 26,76 & $\mathrm{~L}$ & 0,75 \\
$4(0-30)$ & 7,38 & 0,04 & 4,90 & 1,26 & 20,32 & 29,17 & 50,51 & $\mathrm{C}$ & 0,13 \\
$5(0-10)$ & 7,64 & 0,03 & 12,32 & 0,94 & 9,50 & 33,49 & 57,01 & $\mathrm{C}$ & 0,45 \\
$6(0-30)$ & 7,44 & 0,04 & 8,37 & 0,92 & 18,02 & 36,26 & 45,72 & $\mathrm{C}$ & 0,20 \\
$7(0-30)$ & 7,29 & 0,03 & 1,58 & 1,25 & 13,57 & 38,47 & 47,96 & $\mathrm{C}$ & 0,25 \\
$8(0-30)$ & 7,26 & 0,03 & 5,53 & 1,57 & 23,17 & 35,07 & 41,76 & $\mathrm{C}$ & 0,22 \\
$9(0-30)$ & 7,37 & 0,03 & 6,64 & 1,60 & 27,53 & 37,02 & 35,45 & $\mathrm{CL}$ & 0,55 \\
$10(0-30)$ & 7,37 & 0,05 & 4,74 & 1,02 & 22,99 & 35,16 & 41,85 & $\mathrm{C}$ & 0,51 \\
$11(0-30)$ & 7,19 & 0,04 & 4,74 & 1,57 & 59,37 & 18,39 & 22,24 & $\mathrm{SCL}$ & 2,35 \\
$12(0-30)$ & 6,64 & 0,02 & 1,11 & 1,32 & 15,62 & 29,36 & 55,02 & $\mathrm{C}$ & 0,25 \\
\hline
\end{tabular}


yarayıșlı fosfor değerlerinin düșük olduğu belirlenmiștir. Bu durumun düșük pH değerlerine bağlı olabileceği düșünülmektedir (Zin vd., 2015). Marmara Bölgesi topraklarının \% 53,3'ünün yarayıșlı fosfor kapsamı yeterli veya yüksektir ve diğer yandan ise \% 46,7'sinin fosfor kapsamı orta, az veya çok azdır (Tașova ve Akın, 2013). Araștırma topraklarının değișebilir potasyum $\left(\mathrm{K}_{2} \mathrm{O}\right)$ değerleri $26,78 \mathrm{~kg} \mathrm{da}^{-1}$ ile 107,96 kg da'-1 arasında değișiklik göstermektedir. 1, 2, 3, 4, 7, 8, 9, 10, 11 ve 12 no'lu örnekler fazla miktarda (> $40 \mathrm{~kg} \mathrm{da}^{-1}$ ); 6 no'lu örnek yeter miktarda $\left(30-40 \mathrm{~kg} \mathrm{da}^{-1}\right)$ ve $5 \mathrm{no}^{\prime} \mathrm{lu}$

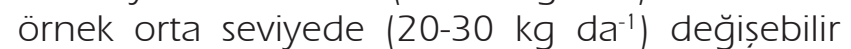
potasyum içermektedir. Değișebilir potasyum için sınıflandırma Anonim (1984)'in bildirdiği sınır değerlerine göre yapılmıștır. 5 no'lu toprak potasyumlu gübre ile yeter seviyeye getirilebilir. Marmara Bölgesi topraklarının \% 81, 1'i potasyum kapsamı bakımından yüksektir (Tașova ve Akın, 2013).

Araștırma topraklarının mikro element içerikleri ile ilgili değerlendirilmesi șu șekildedir: Toprakların yarayıșlı demir içerikleri, 3,80 ppm ile 40,68 ppm arasında değișiklik göstermektedir. Lindsay ve Norvell (1978) tarafından yarayıș̦lı demir için bildirilen kritik değer 4,5 ppm' dir. Orta seviyede yarayıșlı demir içeren 3 no' lu örneğin (3,80ppm) dıșındaki tüm örneklerin yüksek miktarda yarayıș̦lı demir içerdikleri tespit edilmiștir. Yarayıșılı bakır (Cu) içerikleri 1,38 ppm ile 4,84 ppm arasında değișen araștırma topraklarının tümü Lindsay ve Norvell (1978) tarafından bildirilen 0,2 ppm değerinin üzerinde olduğu için yarayıșlı bakır açısından yeterli düzeydedir. Toprakların yarayıșlı çinko değerleri 0,19 ppm ile 1,52 ppm arasında değișmektedir. 8, 9 ve 11 no'lu örnekler yüksek miktarda (> 1 ppm); 1, 2 ve 12 no'lu örnekler orta seviyede $(0,5-1$ ppm); diğer 6 adet örnek te düșük miktarda $(<0,5$ ppm) yarayıșlı çinko (Zn) içermektedir. Yarayıșlı çinko sınıflandırması için Viets ve Lindsay (1973) tarafından bildirilen sınır değerleri kullanılmıștır. Yarayıșlı çinko içerikleri düșük miktarda ve orta seviyede olan topraklara çinko içerikli gübreler verilmek suretiyle çinko yeterli seviyeye getirilebilir.

Yarayıșlı mangan (Mn) değerleri 8,02 ppm ile 53,34 ppm arasında değișen tüm örnekler, Viets ve Lindsay (1973) tarafından mangan için belirtilen kritik değerin (1 ppm) üzerinde oldukları için yüksek miktarda mangan içermektedirler. Marmara Bölgesi toprakları mikro elementlerden demir ve bakır kapsamı yönünden yeterli, \% 54,4'lük kısmı da

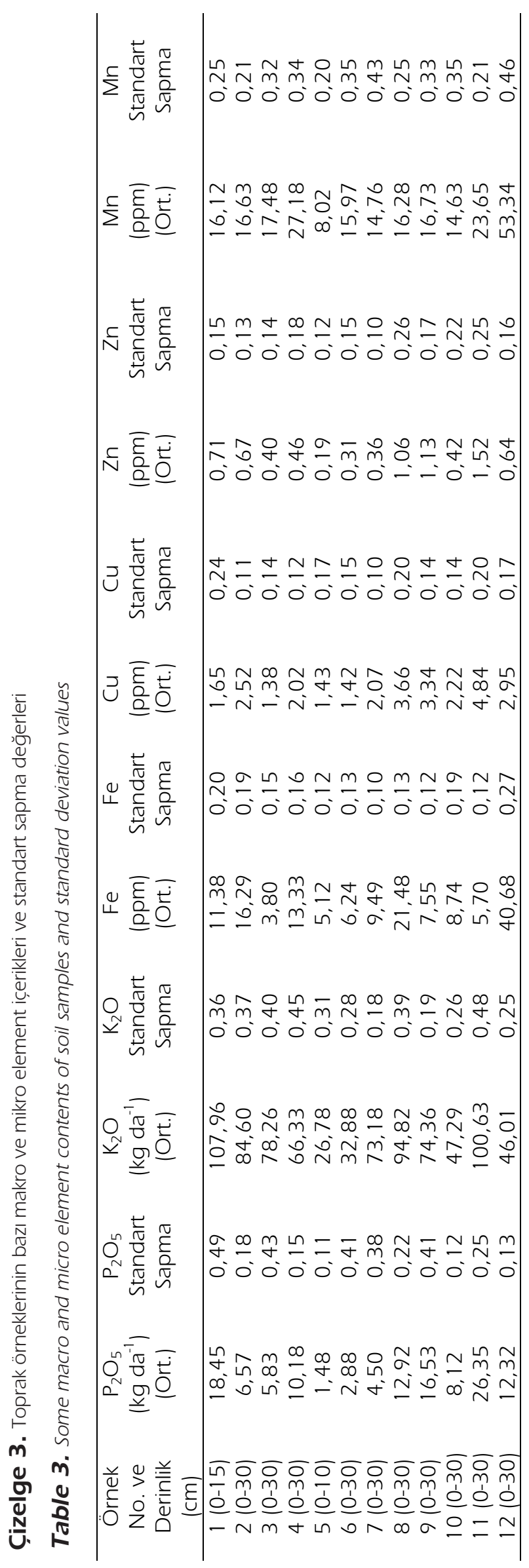


çinko kapsamları yönünden az ve çok az sınıfındandır. Mangan kapsamları ise \% 60, 1 'i az ve çok az düzeyde, \% 39,9'u ise yeterli, fazla ve çok fazla düzeydedir (Tașova ve Akın, 2013). Batı Yunanistan'da, Arta Ovası́nın tarımsal toprağı değerlendirilmiș ve $\mathrm{Co}, \mathrm{Cr}$, Cu, Fe, Mn, Ni ve $\mathrm{Zn}$ için yüksek konsantrasyonlar saptanmıștır. Ancak bunların hareketliliği karbonatların güçlü tamponlama kapasitesinin yanısıra topraktaki yüksek kil ve organik madde içeriği tarafından azaltııır (Papadopoulou-Vrynioti vd., 2014).

Standart sapmanın miktarı yapılan ölçümlerin doğruluğu hakkında genel bir fikir verir (Soysal, 2000). Standart sapmanın büyük olması, varyantların ortalamadan ayrııșlarının büyük (ortalama etrafındaki dağııșlarının fazla) olușu anlamına gelir (Ercan, 1997).

\section{SONUÇLAR}

Tarımsal faaliyetler için önemli potansiyele sahip olan ve çok farklı özellikler gösteren alüviyal toprakların bazı özellikleri bu çalıșmada belirlenmiștir. Çalıșma kapsamında, Tekirdağ Merkez ilçesindeki bazı akarsu yataklarından alınan yüzey toprağı örneklerinin fiziksel ve kimyasal analiz sonuçlarının, akarsu yataklarında yapılmıș olan diğer çalıșmalarla birbirini desteklediği görülmüștür. Araștırma topraklarının büyük bir kısmı kil tekstür sınıfında olup, genellikle yavaș hidrolik iletkenliğe sahiptirler. Toprak reaksiyonlarının neredeyse tamamı nötr olarak bulunmuș ve çalıșmada kullanılan toprakların hiçbirinde tuzluluk sorununa rastlanmamıștır.

Toprak örneklerinin 7 tanesinde kireç miktarı az olarak saptanırken, örneklerin tümünde organik madde azlığı göze çarpmaktadır. Bu araștırmada kullanılan toprak örneklerinde organik madde kapsamının az olması tarımla ilgili yapılacak çalıșmalar için önemli bir problem arz etmektedir. Bașta ahır gübresi olmak üzere çeșitli organik gübrelerin kullanılmasıyla organik maddenin iyi bir düzeye çıkarılması gerekmektedir. Çok düșük miktarda ve orta seviyede yarayıșlı fosfor içeren toplam 7 adet toprak için fosforlu gübrelerin kullanılması önerilmektedir. Toprakların büyük çoğunluğunun değișebilir potasyum kapsamları oldukça yeterlidir. Verimlilik bakımından yarayıșı Zn haricinde yarayıșlı Fe, Cu ve Mn için herhangi bir eksiklik tespit edilmemiștir. 8, 9 ve 11 no'lu örneklerin dıșındaki topraklara çinkolu gübrelerin uygulanması tavsiye edilmektedir.
Gübre kullanımında organik gübrelerin tercih edilmesi, toprakların mevcut fiziksel ve kimyasal özelliklerini korumak ve eksik yönlerini de iyileștirmek için büyük öneme sahiptir. Topraklara uygulanacak olan tarımsal ișlemlerde (toprak ișleme, sulama vb.) dikkatli olunması gerekmektedir.

\section{Teșekkür}

Bu çalıșma Bahadır ATMACA tarafından Namık Kemal Üniversitesi Fen Bilimleri Enstitüsü Toprak Anabilim dalında yapılan doktora tezinin bir kısmını kapsamaktadır. Tez çalıșmasında yardımlarını esirgemeyen değerli hocamı merhum Prof. Dr. Cemil CANGIR'e șükranlarımızı sunarız.

\section{KAYNAKLAR}

Alpaslan M, Güneș A, İnal A (2005). Deneme tekniği 12. Baskı). Ankara Üniversitesi Ziraat Fakültesi Yayın No: 1543, Ders Kitabı: 496, Ankara, 437 s.

Anonim (1972). Tekirdağ ili toprak kaynağı envanter haritası. Köyișleri Bakanlığı Topraksu Genel Müdürlüğü Toprak Etüdleri ve Haritalama Dairesi Arazi Tasnif Șubesi, Bakanlık Yayınları: 164, Genel Müdürlük Yayınları: 247, Raporlar Serisi: 36, Ankara.

Anonim (1984). Tekirdağ ili verimlilik envanteri ve gübre intiyaç raporu. T.C. Tarım Orman ve Köyișleri Bakanlığı Topraksu Genel Müdürlüğü Toprak Etüdleri ve Haritalama Dairesi Bașkanlığı, TOVEP Yayın No: 13, Genel Yayın No: 741, 40 s, Ankara.

Anonim (2015). Google-Earth 7.1.2.2041.Available: http://mww.google.com/intl/tr/earth/index.html (Erișim tarihi: 10.04.2015).

Atmaca B, Boyraz D (2015). Tekirdağ Merkez ilçesi kıyı șeridindeki doğal drenaj ağındaki toprakların zemin mühendisliği özelliklerinin değerlendirilmesi. Tekirdağ Ziraat Fakültesi Dergisi / JOTAF, 12 (2): 47-56.

Bellitürk K, Danıșman F, Sözübek B (2009). Tekirdağ yöresindeki toprakların bazı fiziksel ve kimyasal özellikleri ile mineralizasyon kapasiteleri arasındaki ilișkiler. Akdeniz Üniversitesi Ziraat Fakültesi Dergisi, 22 (2): 141-147.

Bellitürk K, Sağlam M T (2005). Tekirdağ ili topraklarının mineralize olan azot miktarları ile mineralizasyon kapasiteleri üzerinde bir araștırma. Tekirdağ Ziraat Fakültesi Dergisi / JOTAF, 2 (1): 89-101.

Bouyoucos G J (1951). A recalibration of the hydrometer method for making mechanical analysis of soils. Agronomy Journal, 43: 434-438.

Cangir C (1991). Toprak bilgisi. Trakya Üniversitesi Tekirdağ Ziraat Fakültesi Yayın No: 1 16, Ders Kitabı No: 5, Tekirdağ, 178 s.

Dengiz O, Gülser C (2014). Farklı fluviyal depozitler üzerinde olușmuș toprakların dağııım alanlarının belirlenmesi ve sınıflaması. Türkiye Tarımsal Araștırmalar Dergisi, 1 (1): 9-17.

Dengiz O, Sarıoğlu F E (2011). Samsun ilinin potansiyel tarım alanlarının genel dağılımları ve toprak etüd ve haritalama çalıșmalarının önemi. Anadolu Tarım Bilimleri Dergisi, 26 (3): 241-250. 
Durak A, Aydın M E (2014). Yeșilırmak nehir teraslarında toprakların olușumu ve sınıflandırılması. Türk Tarım - Gıda Bilim ve Teknoloji Dergisi, 2 (2): 98-105.

Ercan M (1997). Bilimsel Araștırmalarda İstatistik. Çeșitli Yayınlar Serisi No: 6 (Genișletilmiș İkinci Baskı). T. C. Orman Bakanlığı Kavak ve Hızı Gelișen Orman Ağaçları Araștırma Enstitüsü Müdürlüğü Yayın No: 243, İzmit, 223 s.

Faust D, Diaz del Olmo F, Baena Escudero R (2000). Soils in the Holocene alluvial sediments of the Rio Fraja Valley, Spain: in situ or soil-sediments? Catena, 41 (1-3): 133-142.

Jackson M L (1958). Soil Chemical Analysis. Prentice-Hall, Inc. Englewood Cliffs, New Jersey, USA, p. 498.

Keskin F (1998). Mustafa Kemal Üniversitesi Ziraat Fakültesi Selam arazisi topraklarının temel özellikleri. Yüksek lisans tezi, Mustafa Kemal Üniversitesi Fen Bilimleri Enstitüsü, Antakya.

Lindsay W L, Norvell W A (1978). Development of a DTPA soil test for zinc, iron, manganese and copper. Soil Science Society of America Journal, 42 (3): 421-428.

Olsen S R, Cole C V, Watanabe F S, Dean L A (1954). Estimation of available phosphorus in soils by extraction with sodium bicarbonate. United States Department of Agriculture Circular No: 939, Washington, D C, USA, p. 19.

Olsen S R, Dean LA (1965). Phosphorus. In: C A Black (Ed.), Methods of soil analysis, Part 2, American Society of Agronomy, Madison, Wisconsin, USA, pp. 1035-1049.

Papadopoulou-Vrynioti K, Alexakis D, Bathrellos G D, Skilodimou H D, Vryniotis D, Vassiliades E (2014). Environmental research and evaluation of agricultural soil of the Arta plain, western Hellas. Journal of Geochemical Exploration, 136: 84-92.

Richards L A (1954). Diagnosis and improvement of saline and alkali soils. United States Department of Agriculture Handbook No: 60, USA, p. 159.

Sağlam M T (2001). Toprak ve suyun kimyasal analiz yöntemleri (Genișletilmiș üçüncü baskı). Trakya Üniversitesi Tekirdağ Ziraat Fakültesi Yayın No: 189, Ders Kitabı No: 5 , Tekirdağ, $154 \mathrm{~s}$.
Sarı H (2010). Tekirdağ Merkez Bağlar sırtları mevkii de yer alan toprakların katenasal ilișkilerinin belirlenmesi. Yüksek lisans tezi, Namık Kemal Üniversitesi Fen Bilimleri Enstitüsü, Tekirdağ.

Sinan E (1996). Tekirdağ-Marmara Ereğlisi arasında kalan kıyı bandı topraklarının bazı fiziksel ve kimyasal özellikleri üzerine bir araștırma. Yüksek lisans tezi, Trakya Üniversitesi Fen Bilimleri Enstitüsü, Tekirdağ.

Soil Survey Division Staff (1993). Soil survey manual. Soil Conservation Service, United States Department of Agriculture Handbook No: 18, Washington, D C, USA, p. 437.

Soysal M i (2000). Biometrinin prensipleri (İstatistik I ve II Ders Notları). Trakya Üniversitesi Tekirdağ Ziraat Fakültesi Yayın No: 95, Ders Notu No: 64, Tekirdağ, 332s.

Tașova H, Akın A (2013). Marmara Bölgesi topraklarının bitki besin maddesi kapsamlarının belirlenmesi, veri tabanının olușturulması ve haritalanması. Toprak Su Dergisi, 2(2): 83-95.

Turan M A, Katkat A V, Özsoy G, Taban S (2010). Bursa ili alüviyal tarım topraklarının verimlilik durumları ve potansiyel beslenme sorunlarının belirlenmesi. Uludağ Üniversitesi Ziraat Fakültesi Dergisi, 24 (1): 115-130 .

Tüzüner A (1990). Toprak ve su analiz laboratuvarları el kitabı. T.C. Tarım Orman ve Köyișleri Bakanlığı Köy Hizmetleri Genel Müdürlüğü, Ankara, 375 s.

Viets F G, Lindsay W L (1973). Testing soils for zinc, copper, manganese and iron. In: L M Walsh and J D Beaton (Eds.), Soil testing and plant analysis, Soil Science Society of America, Madison, Wisconsin, USA, pp. 153-172.

Zin K P, Lim L H, Mallikarjunaiah T H, Bandara J M R S (2015). Chemical properties and phosphorus fractions in profiles of acid sulfate soils of major rice growing areas in Brunei Darussalam. Geoderma Regional, 6: 22-30. 